\title{
Bracken Fern Control in Pastures ${ }^{1}$
}

\author{
B. Sellers, J. Ferrell, and T. Wilson ${ }^{2}$
}

Bracken fern is a common perennial widely distributed across the United States (Figure 1). This plant grows well in both wet and dry soil, but seems to prefer semi-shaded environments. Bracken fern is most common along tree lines, in forest openings, and around building borders. Although animals rarely consume bracken fern, they will do so when adequate forage is not available. This is problematic because bracken fern is a well-documented poisonous plant (Knight and Walter 2001). All parts of the plant contain the toxin, but levels are highest in the rhizomes. Generally, horses and swine are most susceptible, while ruminant animals are more tolerant (Knight and Walter 2001). Toxicity from bracken fern (which induces vitamin $\mathrm{B}_{1}$ deficiency) does not usually occur immediately; rather, it is most commonly chronic in nature, requiring repeated exposure to the plant over time. This publication is intended for county Extension faculty as well as owners and managers of grazing lands.

Control of bracken fern has been relatively difficult to achieve becausemost of the commonly used pasture herbicides are ineffective. Research conducted at UF/IFAS has shown that 2,4-D + dicamba (Weedmaster, others), triclopyr (Remedy Ultra, others), and 2,4-D + aminopyralid (GrazonNext HL) are ineffective (Table 1). These herbicides will often cause treated leaves to die, but resprouting from rhizomes occurs quickly. However, metsulfuron (MSM
60 , others) and chlorsulfuron (Telar) have proven to be effective. Nevertheless, some plants began to resprout by eight months after treatment. Considering that bracken fern is a perennial plant, multiple applications may be necessary for complete control. Note that metsulfuron can be safely applied to bermudagrass, but will result in moderate to severe injury if applied to bahiagrass. Chlorsulfuron can be safely applied to both bermudagrass and bahiagrass.

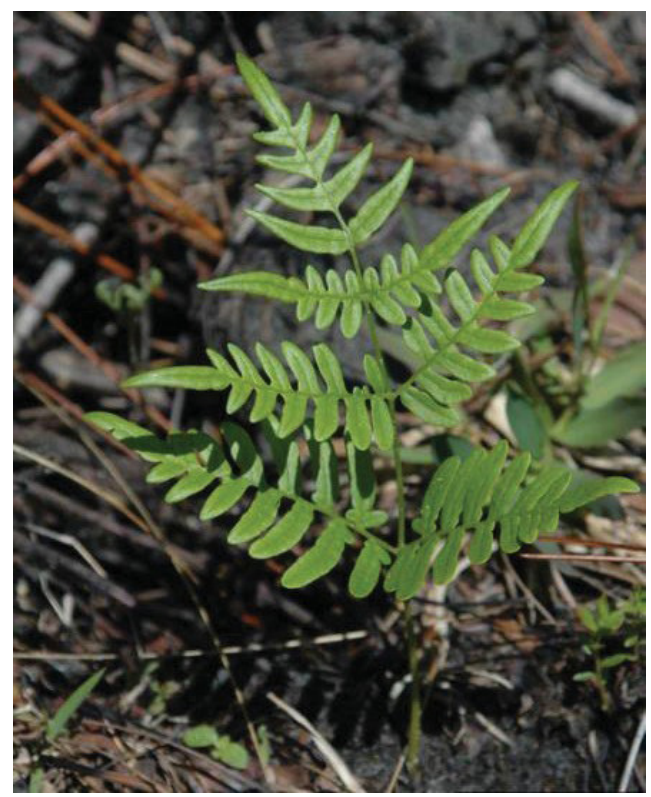

Figure 1. Bracken fern.

Credits: Chris Evans, River to River CWMA, Bugwood.org

1. This document is SS-AGR-357, one of a series of the Agronomy Department, UF/IFAS Extension. Original publication date December 2011. Revised October 2017 and August 2021. Visit the EDIS website at https://edis.ifas.ufl.edu for the currently supported version of this publication.

2. B. Sellers, professor, Agronomy Department, director, UF/IFAS Range Cattle Research and Education Center; J. Ferrell, professor (former author), Agronomy Department; and T. Wilson, county Extension director, UF/IFAS Extension Bradford County; UF/IFAS Extension, Gainesville, FL 32611.

The use of trade names in this publication is solely for the purpose of providing specific information. UF/IFAS does not guarantee or warranty the products named, and references to them in this publication do not signify our approval to the exclusion of other products of suitable composition.

Use pesticides safely. Read and follow directions on the manufacturer's label.

The Institute of Food and Agricultural Sciences (IFAS) is an Equal Opportunity Institution authorized to provide research, educational information and other services

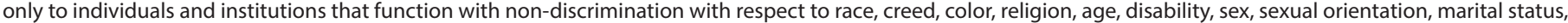
national origin, political opinions or affiliations. For more information on obtaining other UF/IFAS Extension publications, contact your county's UF/IFAS Extension office. U.S. Department of Agriculture, UF/IFAS Extension Service, University of Florida, IFAS, Florida A \& M University Cooperative Extension Program, and Boards of County Commissioners Cooperating. Nick T. Place, dean for UF/IFAS Extension. 


\section{Reference}

Knight, A. P., and R. Walter. 2001. A Guide to Plant Poisoning of Animals in North America. Jackson, WY: Teton New Media.

Table 1. Control of bracken fern with postemergence herbicides. Contact: Brent Sellers (sellersb@ufl.edu).

\begin{tabular}{|c|c|c|c|c|}
\hline \multirow[t]{2}{*}{ Herbicide } & \multirow{2}{*}{$\begin{array}{l}\text { HRAC } \\
\text { MOA }\end{array}$} & \multirow[t]{2}{*}{ Application Rate } & 1 MAT $^{1}$ & 8 MAT \\
\hline & & & \multicolumn{2}{|c|}{$\%$ control } \\
\hline $\begin{array}{l}\text { 2,4-D amine } \\
\text { (Weedar, others) }\end{array}$ & 4 & $2 \mathrm{qt} / \mathrm{A}$ & 90 & 0 \\
\hline $\begin{array}{l}\text { 2,4-D + aminopyralid } \\
\text { (GrazonNext HL, others) }\end{array}$ & 4 & $24 \mathrm{oz} / \mathrm{A}$ & 90 & 0 \\
\hline $\begin{array}{l}\text { Triclopyr ester } \\
\text { (Remedy Ultra, others) }\end{array}$ & 4 & $1 \mathrm{qt} / \mathrm{A}$ & 100 & 0 \\
\hline $\begin{array}{l}\text { Triclopyr + fluroxypyr } \\
\text { (PastureGard HL, others) }\end{array}$ & 4 & $1.5 \mathrm{pt} / \mathrm{A}$ & 100 & 0 \\
\hline $\begin{array}{l}\text { 2,4-D + dicamba } \\
\text { (Weedmaster, others) }\end{array}$ & 4 & $1.5 \mathrm{qt} / \mathrm{A}$ & 95 & 0 \\
\hline $\begin{array}{l}\text { Metsulfuron } \\
\text { (Escort, MSM 60, others) }\end{array}$ & 2 & $0.3 \mathrm{oz} / \mathrm{A}$ & 60 & 95 \\
\hline $\begin{array}{l}\text { Chlorsulfuron } \\
\text { (Telar) }\end{array}$ & 2 & $0.5 \mathrm{oz} / \mathrm{A}$ & 60 & 90 \\
\hline
\end{tabular}

